Images in...

\title{
Extensive calcinosis
}

\author{
G Vivek, ${ }^{1}$ Padmakumar R, ${ }^{1}$ Nitin Kansal, ${ }^{1}$ Shubha Seshadri, ${ }^{2}$ Lorraine Simone Dias ${ }^{2}$ \\ 1Department of Cardiology, Kasturba medical college, Manipal, Karnataka, India; \\ 2Department of medicine, Kasturba medical college, Manipal, Karnataka, India
}

Correspondence to G Vivek, vivekgraman@gmail.com

\section{DESCRIPTION}

A 74-year-old lady was admitted with complaints of breathlessness of 1 -week duration. She had been diagnosed as limited scleroderma, 10 years back; however, she was not on any medications. Chest radiograph was suggestive of alveolar oedema; extensive calcification of soft tissue around the shoulder joints was noted bilaterally (figure 1A, arrows). Additional radiographs revealed calcification around the right shoulder joint (figure $1 \mathrm{~B}$, arrows) and wrist (figure 1C, arrow). The patient had no symptoms related to the same. She had critical stenosis in her left anterior descending artery for which she underwent an angioplasty and stent placement. Calcinosis cutis (Cc) is the deposition of insoluble calcium salts (hydroxyapatite crystals and amorphous calcium phosphates) in the skin. ${ }^{1}$ ${ }^{2}$ First described by Virchow in $1855^{3}$; it is classified into four major types according to aetiology as dystrophic, metastatic, iatrogenic and idiopathic.
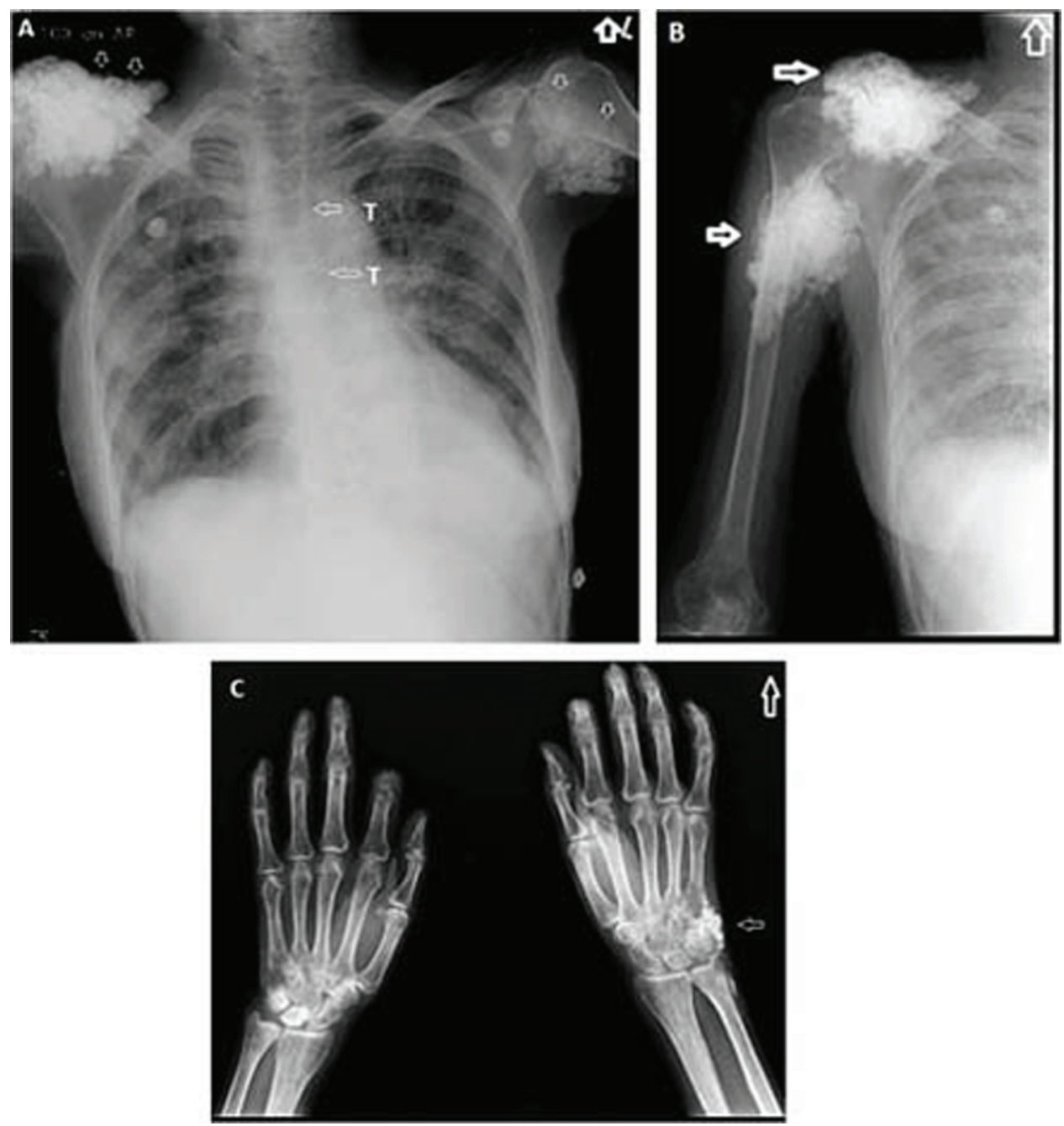

Figure 1 (A) Chest radiograph showing calcification of soft tissue around the shoulder joints bilaterally (arrows). T denotes tracheal calcification. (B) Radiograph of right shoulder joint showing soft tissue calcification (arrows). (C) Radiograph of wrist joints showing calcification (arrow). 


\section{BMJ Case Reports}

Metastatic calcification arises in the setting of abnormal calcium or phosphate metabolism and is generally associated with hypercalcaemia and/or hyperphosphataemia. Examples include hyperparathyroidism, paraneoplastic hypercalcaemia and chronic renal failure. Idiopathic Cc occurs in the absence of known tissue injury or systemic metabolic defect. Examples include idiopathic Cc of scrotum, penis or vulva, Milia-like idiopathic $\mathrm{Cc}^{4}$ and transplant-associated idiopathic Cc. ${ }^{5}$ Iatrogenic Cc arises secondary to parenteral administration of calcium or phosphate, ${ }^{6}$ repeated heel sticks in the newborn, prolonged use of calcium-containing electrode paste in diagnostic procedures such as electroencephalography.

In connective tissue diseases, calcinosis is mostly of the dystrophic type and it seems to be a localised process rather than an imbalance of calcium homeostasis. Serum calcium, phosphorus and alkaline phosphatase levels are typically normal. Calcium deposits may be intracutaneous, subcutaneous, fascial or intramuscular.

Complications of $\mathrm{Cc}$ include pain, cosmetic disfigurement, persistent ulceration with infection and mechanical compromise.

Work-up for Cc includes serum calcium, inorganic phosphate, alkaline phosphatase and albumin. Imaging studies include radiographs, CT and bone scintigraphy. On biopsy, granules and deposits of calcium are seen in the dermis on Von Kossa and alizarin red stains.

The pharmacological treatment is difficult and a variety of drugs including bisphosphonates, intralesional corticosteroids, warfarin and diltiazem have been tried with limited success. The local excision of painful or ulcerated nodule is an option but local recurrence is common.

Competing interests None.

Patient consent Obtained.

\section{REFERENCES}

1. Larralde M, Giachetti A, Cáceres MR, et al. Calcinosis cutis following trauma. Pediatr Dermatol 2005;22:227-9.

2. Touart DM, Sau P. Cutaneous deposition diseases. Part II. J Am Acad Dermatol 1998;39(4 Pt 1):527-44; quiz 545-6.

3. Virchow R. Kalk-metastasen. Virchows Arch Path Anat 1855;8:103-13.

4. Bécuwe C, Roth B, Villedieu MH, et al. Milia-like idiopathic calcinosis cutis Pediatr Dermatol 2004;21:483-5.

5. Lateo S, Charlton F, Hudson M, et al. Cutaneous calcification following liver transplantation. Clin Exp Dermatol 2005;30:484-6.

6. Moss J, Syrengelas A, Antaya R, et al. Calcinosis cutis: a complication of intravenous administration of calcium glucanate. J Cutan Pathol 2006:33(Suppl 2):60-2

This pdf has been created automatically from the final edited text and images.

Copyright 2011 BMJ Publishing Group. All rights reserved. For permission to reuse any of this content visit

http://group.bmj.com/group/rights-licensing/permissions.

BMJ Case Report Fellows may re-use this article for personal use and teaching without any further permission.

Please cite this article as follows (you will need to access the article online to obtain the date of publication).

Vivek G, R P, Kansal N, Seshadri S, Dias LS. Extensive calcinosis. BMJ Case Reports 2011;10.1136/bcr.03.2011.4016, date of publication

Become a Fellow of BMJ Case Reports today and you can:

- Submit as many cases as you like

- Enjoy fast sympathetic peer review and rapid publication of accepted articles

- Access all the published articles

- Re-use any of the published material for personal use and teaching without further permission

For information on Institutional Fellowships contact consortiasales@bmjgroup.com

Visit casereports.bmj.com for more articles like this and to become a Fellow 